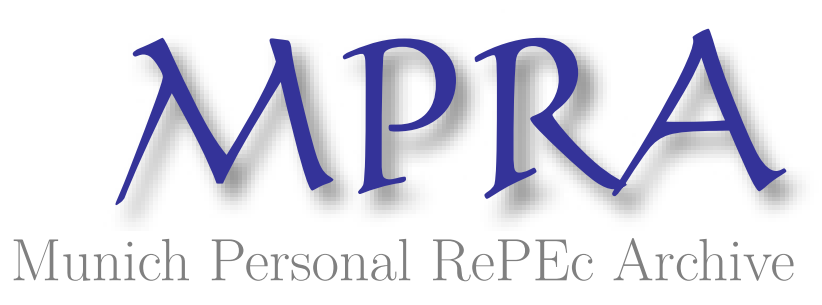

\title{
The genius of Mises and the brilliance of Kirzner
}

Boettke, Peter and Sautet, Frederic

2006

Online at https://mpra.ub.uni-muenchen.de/32088/

MPRA Paper No. 32088, posted 07 Jul 2011 19:21 UTC 


\title{
Department of Economics
}

\section{The Genius of Mises and The Brilliance of Kirzner}

\author{
Peter Boettke \\ and \\ Frederic Sautet
}

George Mason University

Department of Economics

Paper No. 11-05 


\section{The Genius of Mises and The Brilliance of Kirzner}

Peter Boettke, Department of Economics, George Mason University

Frederic Sautet, Mercatus Center at George Mason University

What Mises taught us in his writings, in his lectures, in his seminars, and in perhaps everything he said, was that economics is crucially important. Economics is not an intellectual game. Economics is deadly serious. The very future of mankind-of civilization-depends, in Mises' view, upon widespread understanding of, and respect for, the principles of economics.

— Israel Kirzner (2006)

\section{Introduction}

The neoclassical model of the pure market economy is a frictionless world where the decentralized decisions of agents are coordinated seamlessly through the price mechanism. The neoclassical model of market failure and thus government interventionism, on the other hand, deals with the complications of the real world (i.e. the frictions in the world), and demonstrates how the price system cannot perfectly operate. In this view, government can improve upon the failures of the market.

By contrast, the works of economists such as Armen Alchian, James Buchanan, Ronald Coase, Douglas North, Vernon Smith and Elinor Ostrom fully embrace the frictions that exist in the real world, and attempt to show how market forces work to adjust behavior and change practices in order to ameliorate the imperfections in the world and promote the coordination of plans. The price system is important precisely because we are imperfect actors in an imperfect world of frictions, uncertainty, and human ignorance. 
Ludwig von Mises and Israel Kirzner are two of the most prominent scholars who have attempted to gain a richer understanding of how the invisible hand operates in coordinating the vast array of economic exchanges that occur on a daily basis in the actual imperfect world. The "invisible hand" works precisely because of the imperfections in this vision of market theory, and does not require any of the assumptions associated with the formal theory of general competitive equilibrium - neither large numbers, price taking, homogenous goods, nor perfect knowledge. As Ludwig von Mises (1978: 36) wrote, "[w]hat distinguishes the Austrian School and will lend it immortal fame is precisely the fact that it created a theory of economic action and not of economic equilibrium or non-action". Austrian economists, most notably Mises, Hayek and Kirzner, have sought to demonstrate how human behavior guided by prices, as well as monetary profits and losses, and under a system of private property would adjust and cope with the world's imperfections. This methodology focuses on the institutional structure that creates a unique incentive-based framework that in turn influences the behavior of actors. This behavior includes the dissemination of information which then directly influences the decisions and actions of agents in coordinating their activities and hence in improving the overall efficiency of the economic system. It took some great minds to develop this analysis, and amongst them stand Mises, Hayek and Kirzner. For purposes of this occasion we focus our attention on the unique contributions of Mises and Kirzner.

\section{Mises and the Market}

Israel Kirzner often comments on the reaction he had upon hearing Mises explaining that the market is a process during his course of graduate studies at New York University. Kirzner describes the experience as intellectually jarring. Indeed, he understood what it meant to say "the market was a place", but what could it possibly mean to say, "the market is a process"? Mises meant that the market is not only a space where people may haggle over prices; it is also a process, by which knowledge is generated, information comes to be known, and prices are determined throughout society. The Misesian emphasis over the notion of market as a process is 
what separates traditional market theory from the Austrian view. The market is central in the Austrian approach because it is a process.

Indeed, in the letters between Menger and Walras one can already trace the differences between an approach to the theory of price that focuses on price determination in a system of simultaneous equations on the one hand, and price formation through a process of ongoing bargaining and exchange, on the other. But the leading representatives of the respective schools thought this was merely a difference in emphasis rather than a difference in substance. Hans Mayer (1932) identified in more depth the significant differences between what he called a "functionalist theory" and a "causal-genetic theory" of price. The conscious application of the notion of market process analysis was juxtaposed with general equilibrium theory. While the other leading representatives of the Austrian school in Vienna at the time such as Machlup, Mayer, and Morgenstern clearly understood the importance of market process in economic analysis, it was Mises, Hayek, and later Kirzner who put forth a mature rendering of the Austrian market process analysis.

To understand the origin of market process analysis, one must go back to Mises's The Theory of Money and Credit (1912) in which he employed "period analysis" or the "step-by-step" methodology and sought, way ahead of his time, to integrate micro and macroeconomic theory in developing an analysis of money and the widespread consequences of monetary mismanagement by political authorities. Mises's theory of the business cycle was intimately linked to the way he came to understand the market process. Mises, along with Hayek, worked on questions of business forecasting and what came to be known as the "Austrian theory of the trade cycle." Critical aspects of that theory were: (1) a picture of the capital structure in an economy as consisting of heterogeneous capital good combinations that had to be maintained or reshuffled in more productive and advantageous combinations; (2) a vision of the production process as taking place over time, thus generating a need for a mechanism for the intertemporal coordination of production plans to meet consumer demands; and (3) the notion that increases in the money supply work through the economy not in an instantaneous adjustment of prices, but 
through relative price adjustments. Mises's work both defended the quantity theory of money against monetary cranks that sought to eliminate poverty by printing more money, and criticized the quantity theory as interpreted in mechanical interpretations which postulated instantaneous adjustments of the price system to changes in the quantity of money and therefore underestimated the negative consequences of the manipulation of money and credit by political authorities in an economy.

The link to the market process, while not explicit, was always present in this analysis. Entrepreneurs rely on price signals to guide them in their production projects so that they are allocating scarce capital resources in the most valuable direction and employing the least costly technologies. The capital structure does not automatically replenish itself, but instead requires the careful calculations of economic actors to determine which production plans are the most profitable ones to pursue. If price signals are confusing, then decisions concerning the maintenance and allocation of capital will be mistaken from the point of view of economic value maximization. The monetary theory of the trade cycle developed by Mises and Hayek in the 1920s contrasted a vision of the entrepreneur-based economy with the more mechanistic understanding of a monetary economy associated with economists in the US and the UK, and the chaotic vision of economic life associated with the critics of capitalism.

Contemporaneously with the work on monetary theory and the trade cycle, Mises was embroiled in a debate over the economic feasibility of socialism. Mises' analysis of socialism is, like his monetary theory, based on the subjective theory of value as applied in the context of a capital-using economy. In fact, Mises went as far as to claim: "To understand the problem of economic calculation it was necessary to recognize the true nature of the exchange relations expressed in the prices of the market. The existence of this important problem could be revealed only by the methods of the modern subjective theory of value" ([1922] 1951, p. 186). At the core of Mises's comprehensive critique of socialism lies his understanding of the market process. What makes socialism impossible is not only the perverse incentives of collective ownership and the cumbersomeness of bureaucracy; it is 
more importantly the inability to simulate entrepreneurial innovation outside the context of a market economy and the lure of profit and the penalties of loss.

Indeed, the critical point Mises raised against the most coherent form of socialism was that collective ownership in the means of production would render rational economic calculation impossible. Without private property in the means of production, there would be no market for the means of production. Without a market for the means of production, there would be no market prices for the means of production. In the absence of market prices (reflecting the relative scarcities of capital goods), economic planners would not be able rationally to calculate the most economically efficient investment path. Without the ability to engage in rational economic calculation, production could not be rationally organized. No individual or group of individuals could discriminate between the numerous possibilities of methods of production to determine which ones are the most cost effective without recourse to calculations based on monetary prices. Monetary prices and profit and loss accounting are indispensable guides in the business of economic administration. In their absence, the human mind would be at a loss to decide between different processes of production. Socialism in its attempt to overcome the anarchy of production substitutes instead planned chaos. As Mises puts it:

To suppose that a socialist community could substitute calculations in kind for calculations in terms of money is an illusion. In a community that does not practice exchange, calculation in kind can never cover more than consumption goods. They break down completely where goods of higher order are concerned. Once society abandons free pricing of production goods rational production becomes impossible. Every step that leads away from private ownership of the means of production and the use of money is a step away from rational economic activity. ([1922] 1951, p. 102)

Mises' critique of socialism was greeted with resistance by such figures as Karl Polanyi, Fred Taylor, Oskar Lange, and Abba Lerner. The theoretical discussion among professional economists took place within the historical context of the $1920 \mathrm{~s}$ and especially 1930s, when western capitalist economies were embroiled in the Great Depression while the socialist Soviet system of centralized economic planning 
was understood to have transformed a peasant country into an industrial economy in one generation. Supposedly capitalism was proved by the events of the 1930s to be not only unjust, but also unstable and inefficient. Socialist central planning, on the other hand, provided the Soviet Union with the material base to fight the fascist threat that arose in Germany in the 1930s and 1940s.

All through the debate on the feasibility of socialism, Mises slowly developed a more mature understanding of the entrepreneurial market process. In Socialism (1922), he argued that the price system as a whole serves a three-fold function, which by definition socialism would have to do without. In a market economy, the current array of prices signals to decision makers the relative scarcities of the goods and services in question. If the price is relatively high, it can be inferred that the commodity in question is relatively scarce and thus must be economized in its use, whereas if the price is relatively low, it can be inferred that the commodity in question is relatively abundant and thus can be utilized more. The current array of prices aid decision makers in making decisions by providing ex ante knowledge of the situation. However, the price system also provides ex post knowledge to economic actors in the form of the constellation of prices that emerge in the next period and the profit and loss statements of businesses. If an actor can buy low and sell high, the market communicates that the previous decision was in the right direction, whereas if it is revealed that, based on that earlier knowledge, you bought high and now must sell low, an error in judgment is revealed that needs to be addressed. The very discrepancy between the ex ante expectations set by the array of prices at the moment of decision, and the ex post realizations of profit and loss sets in motion the discovery of better ways to arrange economic activities. These discoveries are made either by the original parties to the transactions or by new parties who enter the fray and bid resources away from the earlier actors. It is through the price system and the constant adjustments of relative prices that economic coordination and continual learning occurs. The strong claims about the market system's ability to self-correct are predicated on the veracity of the price system to achieve coordination and learning. 
With the rise of socialist planning in the world and the support it received from Western intellectuals, Mises decided to continue the fight against what he considered unorthodox and "bad" economics and started writing what would become his magnum opus, first published in 1940 in German and later published in English translation with significant modifications in 1949. In Human Action: A Treatise on Economics (1949 [1966]) Mises skillfully applied and developed the step-by-step methodology to the economics of time, uncertainty, economic calculations, the market economy, the process of price formation, interest, credit expansion, the trade cycle as well as many other topics. In this way, Mises expanded on the work of his Viennese teachers and colleagues in incorporating the dynamic element of the economic process into the analytical framework of modern economics. In Human Action, Mises develops further the idea of the market as a process and shows how market prices are generally "false", or non-equilibrium prices, yet are informationally and motivationally useful in guiding and coordinating economic activity through time. In this context, Mises (1966, pp. 337-8) stated that, "the essential fact is that it is the competition of profit-seeking entrepreneurs that does not tolerate the preservation of false prices of the factors of production. The activities of the entrepreneurs are the element that would bring about the unrealizable state of the evenly rotating economy if no further changes were to occur."

Unlike what Walras had assumed, prices do not reflect all the knowledge available. Because prices don't reflect all available knowledge, discrepancies exist which create pockets of profit that entrepreneurs may discover. In other words, the communication system is not perfect; prices do not convey all the knowledge that Walras would like them to convey. However, it is precisely in this "imperfection" that lays the engine of the economic system. The imperfection of prices is what creates the ability of the system to communicate information concerning its own faulty communication properties.

Ultimately, the notion of market as a process in Mises's work rests on the idea of interconnectedness among human activities (i.e., "connexity" as Mises puts it). The connexity of the market can only be explained if one views the market as a 
process. The mechanism that creates the connexity of human activities is entrepreneurial monetary calculations. Its consequence is social cooperation under the division of labor upon which economic growth and development depends. This mechanism rests on the existence of private property, freedom of contract, and a medium of exchange. As money is present in all exchanges and thus links together the decisions of everyone by virtue of being a medium of exchange, entrepreneurs are able to discover opportunities that may require, for their exploitation, a large division of labor and knowledge. The simultaneous exploitation of numerous entrepreneurial discoveries creates a concatenation of affairs among the various economic actors because entrepreneurs bid resources away from their alternative uses. This bidding process (based on entrepreneurial monetary calculation) creates interconnectedness among human activities. Prices are not isolated elements in the marketplace; they result from the complex relationships that prevail at any moment in society, and upon which the material, scientific and technological advances of western civilization rests.

\section{Kirzner and entrepreneurial discovery}

Israel Kirzner has described his graduate education in economics at New York University as one of profound confusion and intellectual enlightenment. One night a week he learned standard price theory through close study of George Stigler's Theory of Price (1946) and on another night of the week he learned about the market process from Ludwig von Mises and his Human Action (1949). Both approaches were diametrically opposed to the macroeconomics of Keynesianism that was also taught at the time, but they also seem to oppose each other in a fundamental sense. It is against this background that Israel Kirzner developed his market process theory. In a series of books starting in 1960 and spanning more than three decades, Kirzner rigorously developed the modern Austrian theory of market process, specifically in the context of the role of the entrepreneur.

The brilliance of Kirzner rests in the way he opened the closed framework of traditional microeconomics by introducing the entrepreneurial element. In Walras's view, prices are parameters in the system that no agent can influence. Everyone is a 
price taker and prices convey sufficient information for every individual to make choices. Walras labored to solve the following problem. While prices are best seen as parametric from the perspective of each agent, they are seen as variables from the point of view of the system as a whole. In general equilibrium theory, prices are not under the influence of anyone in particular but are determined at the systemic level to clear markets. Prices are seen as conveying sufficient knowledge for agents to allocate resources to their most valued use, are incentives for action, and as such, they convey the necessary information for resources to be allocated efficiently.

This approach raises an immediate issue. If one adopts a parametric view of prices, it falls short of explaining how prices are determined at the system-wide level. The Walrasian dichotomy between prices as parameters for individuals and prices as variables at the system-wide level has propelled market theory into a corner. "How are market prices arrived at?" is the question that the Walrasian system of perfect competition cannot answer-except by stipulating the existence of a fictitious agent, the auctioneer. As Frank Hahn (1973) argued, this view has robbed economics of the ability to explain price changes and actual adjustments. As Arrow put it:

Even if we accept this entire story [that of general competitive equilibrium], there is still one element not individual [i.e. not chosen by individuals]: namely, the prices faced by firms and individuals. What individual has chosen prices? In the formal theory at least, no-one. They are determined on (not by) social institutions known as markets, which equate supply and demand. ... The failure to give an individualistic explanation of price formation has proved to be surprisingly hard to cure." (1994: 4).

In this view of market theory, agents are passive in the sense that they do not originate change, they just respond like robots to the situation of the market and the incentives offered by parametric prices.

Ultimately, the parametric/incentive view of prices rests on a specific view of the economic problem and of knowledge. The Walrasian approach treated resources in the economy as fully known and given. Hayek in 1937 criticized this view by explaining unless one provides a theory of the acquisition of knowledge; 
one cannot explain the allocation of resources and the true role of prices. With Hayek, the economic problem becomes not only one of allocation of resources but one of acquisition and communication of knowledge, which is necessary for individuals to make the best allocative choices possible. Only by providing a solution to that problem, can one offer a solution to the determination of prices. Establishing the right economic problem led Hayek to focus on the nature of knowledge. The Walrasian approach treats knowledge as given, while the Hayekian view sees knowledge as dispersed and not available to all. If knowledge is idiosyncratic and tacit, then prices cannot be treated as parameters that convey all the existing information. Instead they are communicators of knowledge that individuals both determine and use as determinants in their choices.

Again, this is where Kirzner's brilliance lies: in providing a solution to the conundrum of price theory, i.e. the determination of prices. As Kirzner saw it, the problem of entrepreneurship as an analytical category stems from the insight that we cannot explain the existence of sheer novelty (and pure profit) referring to productive factors already in use. Kirzner presented the profession the most daring solution, confronting head-on the problem of change and novelty by devising a theory that could account for the presence of pure profit in the market by focusing on the pure entrepreneurial element in human action. To that end, he distinguished optimizing behavior from entrepreneurial alertness. Isolating the two functions led him to posit the distinction between entrepreneurship and asset ownership. Kirzner also used the equilibrium construct as a foil against which he could study the role of the entrepreneurial function. For it is only against a background of optimizing agents (i.e. Robbinsian maximizers to use Kirzner's terminology) that one can illumine the role of the entrepreneur.

The essence of entrepreneurship in Kirzner's work also revolves around the fundamental idea that the discovery and exploitation of gains from trade does not take place automatically, but rather stems from purposeful human action. This departs from traditional microeconomics in which existing gains from trade are always known. Instead, Kirzner emphasizes that in order for these gains to be exploited, they first have to be noticed. The essence of the entrepreneurial function 
rests on this fundamental insight. In contrast with traditional microeconomics, Kirzner's view of the entrepreneurial function in the market process consists primarily in liberating human choice from its deterministic structure by introducing alertness. Alertness to unexploited gains from trade sets the market process in motion. Thus, it is also because of its relationship to market process that the notion of alertness is crucial.

A key foundation of Kirzner's market process theory is that the underlying variables, including tastes, technology, resource endowment, and the induced variables of profit and loss accounting are in a lagged but determinant relationship. That is, given the dynamics of the economy, the underlying variables, at any one point in time, are not perfectly aligned. The market discovery process provides the mechanism, through which the induced variables move in the same direction as the underlying variables. Overall, Kirzner's contribution to market process theory provides the missing link to the neoclassical theory. Given an institutional framework of private property, low barriers to entry, and frozen underlying variables, the process of entrepreneurship will lead to a pattern of production and exchange, which would guide the economy toward a state of equilibrium. The missing link in traditional price theory that Kirzner provided was an understanding of the disequilibrium foundations of the economy as well as the path from disequilibrium to a state of equilibrium (if and only if underlying variables are frozen).

When individuals determine prices, they act as entrepreneurs. This means that the marginal condition price theory has established (price equals marginal cost) is not an assumption going into the theory. Rather it is a tendency of a competitive market process that results from individuals acting upon the discrepancies that may exist between their own knowledge and the knowledge available in the marketplace. The foresight of the entrepreneur is to discover the value of some knowledge that he posses but which is not yet reflected in market prices.

What distinguishes Austrian economists is the elaborate understanding of the role of the entrepreneurial function and how it gives rise to the market process. 
The traditional understanding of the market is limited because it rests on a "closed" framework, which cannot account for novelty. Kirzner has drawn attention to the open-ended environment in which "relevant opportunities may exist without their having, at the outset of the analysis, already been recognized." As Kirzner explains, in an open-ended framework "there are no known limits to the possible. An economics which seeks to grapple with the real-world circumstance of openendedness must transcend an analytical framework which cannot accommodate genuine surprise. Austrian economics has sought to accomplish this goal by focusing attention on the nature and function of pure entrepreneurial discovery." (Kirzner 2000)

\section{The refinement of the market process}

The entrepreneurial role is one of a discoverer of information that was hitherto unknown. This discovery process rests on the capacity of entrepreneurs to notice information that is not presently conveyed by prices and to act upon it. Entrepreneurs act upon the knowledge they possess of the circumstances around which trades could take place. When an entrepreneur proposes a new good at a new price because she believes that enough people will be interested in her new product to make it worthwhile to produce it, she introduces new knowledge in the system, thereby reducing ignorance. The price system, in its inability to convey all information, creates the incentives to discover what is missing. The entrepreneurial role ultimately is one of discovering knowledge and thereby reducing ignorance.

Ignorance is always present. It is not, however, of the same nature in the open-system as it is in the closed competitive equilibrium. In the former, ignorance is radical because it pertains to ignorance itself: individuals do not know what they do not know. This implies a world where "true uncertainty" exists, that is, where future events are truly unpredictable. It is because of this context of radical ignorance and true uncertainty that the Hayekian economic problem is real.

Assuming the problem away, as competitive equilibrium does, reduces the economic problem to a mechanistic issue (i.e., which prices clear markets?), as opposed to an epistemic one (i.e., how can the system self-correct?). 
In this context, the entrepreneurial function, this unique human characteristic, offers a response to the challenge of radical ignorance. The veil of ignorance is continually under attack because human imagination is always at work. It is important to emphasize that human imagination, the possibility of sheer creation of information, is the principal characteristic of the entrepreneurial function. However, in the social context, creativity is necessary but often not sufficient. What is also needed is a compass to determine, as Joseph Schumpeter emphasized, that invention (i.e., creativity) is also innovation (i.e., socially useful creativity). This compass is the profit and loss mechanism, which helps determine whether invention is socially useful and thus becomes innovation and is adopted by others. The two sides of the entrepreneurial coin are sheer creativity (of information) and discovery (of a knowledge gap in the social fabric through the price mechanism). These two aspects of entrepreneurship are the make up of the market process (i.e., the constant discovery of socially relevant inventions). In this sense, the market process is a self-correcting system based on the discovery of hitherto ignored possibilities for trade. These possibilities for trade reflect at once the discovery of a social need that was not already expressed in the market (and thus was not transmitted by the price system) and the expression of human creativity.

\section{Conclusion}

The intellectual landscape of modern political economy has shifted considerably since the Classical period of the 19th century. In the 20th century, economists sought to refine the universal principles of their discipline by expressing them in a more formal language with all the restrictive assumptions that needed to be employed to assure mathematical tractability. The entrepreneurial element of human action was a casualty of this mathematical revolution because it defies tractability. Both Mises and Kirzner at respective moments in the development of the discipline sought to reemphasize that the market is a process operating in an open-ended universe. One cannot explain the operation of the market and the adjustments of the price system without recourse to the entrepreneur. 
For almost three quarters of a century, economic discourse has embarked on a detour in which the role of the entrepreneur within the market economy is systemically ignored. Against this tide, Ludwig von Mises's genius provided an inspiring vision upon which Kirzner developed his theory of market process during the second half of the century. Kirzner understood well the implications of the idea that optimizing behavior cannot explain the market as a process. Without the introduction of ad-hoc exogenous elements, economics is limited in its capacity to explain social change and novelty. This is not to say that the equilibrium construct is to be jettisoned; it occupies an important place in the toolbox of the economist, as it is only against equilibrium, seen as a foil, that one can understand change.

Economics, however, focused so much on the absence of change that it became detrimental to what economists were trying to explain. In this sense, Kirzner's brilliant research is fundamental, as it puts the notion of change - and entrepreneurial action in the face of the changing conditions - back at the center of economic theory and in particular our understanding of the market economy and the price system.

\section{References}

Arrow, Kenneth 1994. Methodological Individualism and Social Knowledge. The American Economic Review, 84 (2), Papers and Proceedings, 1-9.

Hahn, Frank. 1973. On the Notion of Equilibrium in Economics. Cambridge, University Press.

Hayek, Friedrich. A. 1937. Economics and Knowledge. Reprinted in Hayek, Friedrich. A. ed. 1948 Individualism and Economic Order. Chicago, University of Chicago Press.

Kirzner, Israel. M. 2006. Lifetime Achievement Award Acceptance Speech. Society for the Development of Austrian Economics. Charleston, SC. November. 
Kirzner, Israel. M. 2000. Foreword. In Sautet, Frederic. 2000. An Entrepreneurial Theory of the Firm. London, Routledge.

Mayer, Hans. 1932. Der Erkenntniswert der Funktionellen Priestheorien. Translation, 1994. The Cognitive Value of Functional Theories of Price. In Kirzner, Israel. M., ed. Classics in Austrian Economics: A Sampling in the History of a Tradition, Volume II: The Interwar Period. London, Pickering and Chatto.

Mises, Ludwig. 1978. Notes and Recollections. Illinois, Libertarian Press.

Mises, Ludwig. 1949 [1966] Human Action: A Treatise on Economics. San Francisco, Fox Wilkes.

Mises, Ludwig. 1922 [1981] Socialism. Indianapolis, IN, Liberty Fund.

Mises, Ludwig. 1920 [1990] Economic Calculation in the Socialist Commonwealth. Auburn, AL, Ludwig von Mises Institute.

Mises, Ludwig. 1912 [1980] The Theory of Money and Credit. Indianapolis, IN, Liberty Press.

Stigler, George. 1946. Theory of Price. Chicago, University of Chicago Press. 